UDK: 78.073-057.874

Original scientific paper

\title{
STUDENTS' MUSIC PREFERENCES TOWARDS CLASSICAL MUSIC
}

\author{
Antonella Mendiković Đukić \\ Academy of Music in Pula \\ Juraj Dobrila University of Pula \\ Republic of Croatia \\ antonella.mendikovic.djukic@unipu.hr \\ Marlena Plavšić \\ Faculty of Humanities \\ Juraj Dobrila University of Pula \\ Republic ofCroatia \\ marlena.plavsic@unipu.hr

\section{Sabina Vidulin} \\ Academy of Music in Pula \\ Juraj Dobrila University of Pula \\ Republic ofCroatia \\ sabina.vidulin@unipu.hr
}




\section{ABSTRACT}

Music preferences can be related to many groups offactors, as LeBlanc's Interactive theory of music preference suggests. In this research four factors from the model were explored in relation to students' preference towards classical music: students' age, their gender, their attendance of extracurricular music activities and familiarity of music pieces. Fifteen excerpts of classical music pieces from different musical-historical periods were presented to a sample of 516 students, 7 to 18 years old. Results reveal moderate negative correlation between age and preference towards classical music. Higher preference was found in female students and for familiar pieces. Students that attended extracurricular music activities preferred only some excerpts more. Findings provide strong support to LeBlanc's model. Implications for teaching are proposed.

Key words: age, gender, music education, familiarity, LeBlanc's model. 


\section{INTRODUCTION}

Music Culture, as a subject in Croatian compulsory schools, is conducted one hour per week from the 1 st to the 8 th grade ${ }^{1}$. In Croatian secondary schools ${ }^{2}$ the subject Music Art is also taught for one hour weekly, but only in gymnasiums ${ }^{3}$ and certain vocational schools. It is mostly taught for four years in gymnasiums and for two years in vocational schools. According to the Kurikulum za nastavni predmet Glazbene kulture za osnovne škole i Glazbene umjetnosti za gimnazije (2019) [Curriculum for the subject Music Culture for Compulsory Schools and Music Arts for Gymnasia], there are three domains in this subject: domain A consists of listening to and understanding music, domain $\mathrm{B}$ comprises expressing through music, while domain $\mathrm{C}$ is oriented to music in context. The prescribed contents are realised in different ways because a flexible didactical organisation is recommended, which enables teachers to choose methods, forms and conditions for achieving the programme goals. With childrens' musical experience, musicianship and music understanding, the basics of music culture are acquired and musical skills developed.

Listening to music and music understanding is recommended to increase the quality of listening experiences, train students to think critically, and accept different experiences and contexts. "By actively listening to music, students will get to know music of different types, styles and genres, advance their knowledge of musical components and different levels of musical organisation and experience, understand and learn to value music." (Kurikulum, 2019, 6).

Classical music is central to the music education curriculum, but it does not correspond necessarily to students' music preference and taste. Music preference refers to a short-term liking of certain music, while music taste refers to a general pattern of individual preferences, making it more comprehensive and longerlasting (Hargreaves, North, Tarrant, 2006).

A study done by Šulentić Begić and Begić (2014) revealed that most students in a gymnasium claimed to like listening to classical music in music classes, but they did not consider that it influenced the shaping of their music taste. On the other hand, Vidulin (2013) found that students of compulsory and secondary schools did not put classical music on the top of their preference list, but they considered that music education at school affected their music taste. Students' preference for music played in class could influence various aspects of their experience, such as

1 The first grade starts at the age of 7.

2 The first grade starts at the age of 15.

3 Gymnasium is a traditional name for grammar school. 
enjoyment in music, the wish to perform and practice music, on-task behaviour, and musical growth (Droe, 2006). Therefore, it is useful for teachers to know about factors that are connected with students' preference towards classical music because it can help them in adapting their teaching methods to be more efficient.

The influence of music education as well as of other factors on music preference can be traced in LeBlanc's Interactive theory of music preference (1982). The model consists of eight hierarchically structured levels, and it explains how decisions are made about listening preferences. The lowest, level 8, refers to the input variables, including aspects of the musical stimulus, but also societal variables, such as media, family, peers and educators. Level 7 includes physiological enabling conditions, level 6 involves listener's basic attention, while level 5 tackles his/her current affective state. Level 4 is rather comprehensive and comprises listener's auditory sensitivity, musical ability, memory, personality, training, sex, ethnicity, socioeconomic status, and maturation. At levels 3,2 and 1 listening preference is defined through brain processing, decision point, and preference judgment (acceptance or rejection). So, the model reveals that music education can be influential on music preferences at the input level (level 8) as well as at the fourth level, where music training is listed. Some factors from the fourth level will be explored in this research, related to music preferences: age (as indicator of maturation), gender, extracurricular music education, and familiarity with music (as memory).

\section{Age}

Music preference in humans can be traced to the earliest age. New-borns prefer music that they were exposed to while in the womb (Ullal-Gupta et al., 2013). Infants listen longer to happy-sounding songs than to songs that are less affectively positive (Corbeil et al., 2013; Costa-Giomi, Ilari, 2014). In a meta-analysis Hargreaves, North and Tarrant (2015) found general support to LeBlanc's (1982) hypotheses that: 1) younger children are more open-eared; 2) open-earedness decreases as they become adolescents; 3 ) it partly rebounds as adolescents reach young adulthood; and 4) open-earedness again decreases toward the old age. They revealed that the decline in open-earedness in later childhood usually starts around the age of 10 or 11 years. It can be observed as a very strong preference for a narrow range of pop styles with simultaneous aversion towards all other styles. Afterwards, there seems to be a general decrease in popular music preference across the rest of the lifespan, and a coinciding general inclination towards classical styles, although this does not necessarily refer to more contemporary art music (Hargreaves, North, Tarrant, 2015). Madsen and Geringer (2015) confirmed that preschool children manifested a wider repertoire of music preferences, then open- 
earedness declined till adolescence when, for example, preference towards classical music was lowest, after which young adults widened the span of music preferences.

Research on music preferences in Croatia support these findings. Adolescents aged 14 or 15 tend to rank classical music lower than children aged 9 to 10 and older adolescents or young adults (Dobrota, Mikelić, 2012; Dobrota, Reić Ercegovac, 2017; Reić Ercegovac, Dobrota, Surić, 2017; Trbojević, 2019; Vidulin-Orbanić, 2012; Vidulin, Milovan Delić, Valić, 2020).

\section{Gender}

There is evidence that differences in music preferences regarding gender exist to some extent. It can be found that men prefer rap/hip-hop (Radoš, 2014), while women prefer music of moderate and lower tempo (Dobrota, Mikelić, 2012), pop, r'n'b and latino music (Radoš, 2014), or music that can reflect unpretentious factor, such as pop, country and spiritual music (Bonneville-Roussy et al., 2013). Among Croatian girls, preference was noticed for classical music, but the preference among them also spread to a wider range of music genres, while boys slightly preferred world music (Radočaj-Jerković, Škojo, Milinović, 2018). In a recent study in Croatia and Slovenia it was found that men preferred intense-rebellious style of music, while women preferred reflective-complex music style, but no differences were observed in liking traditional and contemporary ethno or energetic and rhythmic music style (Dobrota, Reić Ercegovac, Habe, 2019). Authors conclude that women prefer music that enables the expression of feelings and bonding with family, while men prefer music that reflects political opinions. In another, slightly older research, again differences were found, but men preferred reflexive-complex as well as intense-rebellious music, while women preferred music that was upbeat, conventional, energetic and rhythmic (Clark, Giacomantonio, 2015). The authors explain that such results reflect women's focus on outlook, relationships, and acceptance, while men focus on individualism and anxiety. Among students that attend music secondary school in Croatia differences can also be observed. Brđanović (2014) found males' preference towards funk and blues, and females' preference towards musical, world music, classical and pop music. It has also been found that women use music more for mood regulation, while men use it more to form their identity and leave an impression (North, Hargreaves, O'Neill, 2000).

Colley (2008) does not find gender differences in music preferences surprising since gender is the primary social distinction. Although men and women share similar taste in many music genres, the reason for women's preference towards lighter music (e.g. mainstream pop), and men's preference for heavy metal/rock music can be connected to the traditional gender-role-related attributes and 
themes expressed by certain music. Mainstream pop music is mainly concentrated on emotions and relationships, which is traditionally expected to be in the women's focus. On the other hand, heavy metal/rock music expresses more domination, aggression and rebel, which is more related to men. Gender roles are a result of upbringing, so music preferences reflect the typical social expectations from girls and women to fit into society, while boys and men are encouraged to be brave and cross the boundaries.

\section{Music education}

Studies generally confirm that people with higher music education and more developed music abilities prefer more complex music, such as classical or jazz (Getz, Marks, Roy, 2014; Dobrota, Reić Ercegovac, 2014). Authors argue that persons with more music education perceive music more cognitively, not just emotionally. People with higher music education also tend to have a broader span of music preferences (Dobrota, Reić Ercegovac, 2014; Elvers et al., 2015; Ginocchio, 2009; Habe, Dobrota, Reić Ercegovac, 2018). At a younger age there is evidence that children that attend the choir have higher preference towards classical music compared to children that attend only regular music lessons at school (RadočajJerković, Škojo, Milinović, 2018). In further formal education it can be observed that students of different school programmes have at least slightly different music preferences, so for example, gymnasium students prefer classical music and world music more than vocational school students (Škojo, 2019). On the other hand, there is evidence that additional music education does not necessarily affect preference towards certain music genres (Dobrota, Curković, 2016; Dobrota, Reić Ercegovac, 2017; Hash, 2009).

The main comment to the research that found a positive correlation between music education and music preferences is that the results are very likely mediated and moderated by other variables. It can be assumed that children with higher musical abilities enrol to extracurricular music activities more frequently than other children. The socio-economic status can moderate the correlation, too since children from families that nurture a certain music taste or that have better resources can afford to attend extracurricular activities.

Experimental studies are rarely found in this field. In one of them, Peery and Peery (1986) trained children in the experimental group in classical music through various music and non-music activities over a 10 months' period. After that period children from the experimental group reacted more positively towards classical music compared to the control group that even showed a decrease in the preference toward it. 


\section{Familiarity}

There is abundant evidence that people prefer music that is familiar to them to the music that is not (e.g. Williams 2016; 2018). It has been proved in a research on everyday listening to music, such as listening to music on the radio (Ward, Goodman, Irwin, 2014). It is confirmed for both authentic and arranged versions of music (Demorest, Schultz, 2004). Familiarity can even be a stronger predictor in choosing music than affective states (Kim, 2011). Repeated exposure to certain music pieces can not only increase preference to that music, but even transfer the preference to the similar yet unfamiliar music pieces within the same genre (Johnston, 2016). Hargreaves, North and Tarrant (2015) argue that preference towards more complex music can be connected with more exposure to it over the time: the more it is listened to, the more likely it becomes understandable. While listening to familiar and unfamiliar music, different brain regions are activated (Freitas et al., 2018).

The purpose of this research was to examine students' preferences towards classical music. The objectives were to explore: the relationship between age and music preferences (1), possible differences in music preferences regarding students' gender (2), their attendance of extracurricular music activities (3), and regarding the familiarity of a music piece (4).

According to the literature, it was hypothesised that preference toward classical music will negatively correlate with age (1), and that higher preference will be found in female students (2), students that attend extracurricular music activities (3) and for more familiar music pieces.

\section{METHOD}

\section{Sample}

The research gathered 516 Croatian students attending different grades: 69 attended the $2^{\text {nd }}, 86$ attended the $5^{\text {th }}$, and 83 attended the $8^{\text {th }}$ grade of compulsory school, 138 students attended the $2^{\text {nd }}$ grade and 140 students attended the $4^{\text {th }}$ grade of gymnasium. Female students $(\mathrm{N}=293)$ slightly outnumbered male students $(\mathrm{N}=223)$. Approximately one third of the sample $(\mathrm{N}=174)$ took part in extracurricular music activities (music or dance lessons). No differences were found between girls and boys, considering their attendance of the extracurricular music activities: 108 girls attended, 185 did not attend while 66 boys attended and 157 boys did not attend them $\left(\chi^{2}=2.99, \mathrm{p}>0.05\right)$. 


\section{Instruments and procedure}

A questionnaire was developed for assessment of students' preferences towards 15 music excerpts. After listening to each music excerpt, students marked how much they liked it on a five-point scale $(1=I$ do not like it at all; $2=I$ do not like it; 3 I like it moderately; 4 = I like it; 5 = I like it a lot). Each music excerpt lasted for 30 seconds from the start of the music piece. An equal number of excerpts were taken from five music periods and styles: Baroque era (The Hen by J.-P. Rameau, Brandenburg concerto no. 2, I. Allegro by J. S. Bach, and Spring, op. 8 RV 269, I. Allegro by A. Vivaldi), Pre-classic and Classical era (Menuet, op. 11, no. 5 (G 275) by L. Boccherini, Sonata Pathétique op. 13 no. 8, I. by L. van Beethoven, A Little Night Music (Serenade no. 13 for strings in $G$ major, K 525) by W. A. Mozart), Romantic era (A Midsummer Night's Dream, Wedding March, op. 61 by F. Mendelssohn, Piano Concerto No. 1 in B-flat minor for piano and orchestra by P. Ilych Tchaikovsky, and Nocturne, op. 9, no. 2 by F. Chopin), Impressionism (Pavane, op. 50 by G. Fauré, Prelude to the Afternoon of a Faun, L 86 by C. Debussy, and Bolero by M. Ravel), and 20th century music (Threnody to the Victims of Hiroshima by K. Penderecki, Rhapsody in Blue by G. Gershwin, and Structures I by P. Boulez). All the chosen pieces were instrumental, less popular and not part of the music education curriculum.

Other variables were explored with closed-ended questions about the music piece recognition (familiar/not familiar) and extracurricular music attendance (attend/do not attend), while gender and age were asked as open-ended questions. Age was expressed as school grade: compulsory school $2^{\text {nd }}$ (7-8 years old), $5^{\text {th }}(10-$ 11 years), $8^{\text {th }}$ (13-14 years), and gymnasium: $2^{\text {nd }}$ (15-16 years old) and $4^{\text {th }}(17-18$ years old).

The research was implemented in schools during Music Culture/Music Art lessons. Students were informed about the procedure and about their anonymous filling of the questionnaire. After each music excerpt they answered the questionnaire. The music excerpts were played in the same order in all the classes. The procedure took between 20 and 25 minutes. 


\section{RESULTS AND DISCUSSION}

\section{Age}

In order to explore the relationship between age, expressed as school grade, and music preference, Spearman's $\rho$ coefficient was calculated for each music pieces. Results are shown in Table 1.

Table 1. Correlation of school grades (age) and music preference

\begin{tabular}{cc}
\hline Music piece & Spearman's $\rho$ \\
\hline P. Ilych Tchakovsky: Piano Concerto No. 1 in B-flat minor for piano and orchestra & $0.16^{* *}$ \\
\hline L. van Beethoven: Sonata Pathétique op. 13 no. 8, I. & $-0.30^{* *}$ \\
\hline K. Penderecki: Threnody to the Victims of Hiroshima & $-0.41^{* *}$ \\
\hline J. S. Bach: Brandenburg concerto no. 2, I. Allegro & $-0.30^{* *}$ \\
\hline W. A. Mozart: A Little Night Music (Serenade no. 13 for strings in G major, K 525) & $-0.22^{* *}$ \\
\hline C. Debussy: Prelude to the Afternoon of a Faun, L 86 & $-0.19^{* *}$ \\
\hline F. Chopin: Nocturne, op. 9, no. 2 & -0.01 \\
\hline A. Vivaldi: Spring, op. 8 RV 269, I. Allegro & $-0.20^{* *}$ \\
\hline G. Gershwin: Rhapsody in Blue & -0.05 \\
\hline F. Mendelssohn: A Midsummer Night's Dream, Wedding March, op. 61 & -0.08 \\
\hline L. Boccherini: Menuet, op. 11, no. 5 (G 275) & $-0.36^{* *}$ \\
\hline J.-P. Rameau: The Hen & $-0.28^{* *}$ \\
\hline G. Fauré: Pavane, op. 50 & -0.04 \\
\hline P. Boulez: Structures I & $-0.36^{* *}$ \\
\hline M. Ravel: Bolero & $-0.26^{* *}$ \\
\hline
\end{tabular}

${ }^{* *} p<0.01$

Results in Table 1 show that 11 of 15 music pieces moderately correlate with students' age. Ten of eleven correlations are negative, which supports the first hypothesis. This result supports previous findings regarding the decline of children's open-earedness in the observed age, 7 to 18 years of age (e. g. Dobrota, Mikelić, 2012; Hargreaves, North, Tarrant, 2015; LeBlanc, 1982; Madsen, Geringer, 2015; Vidulin-Orbanić, 2012). For adolescents it is well established that they prefer music that is listened by their peers (Delsing et al., 2008), and classical music does not fit into that category. However, it can also be hypothesised that the didactical approaches do not adapt adequately to children's developmental changes. So this poses a great challenge to teachers in music education. With the aim to sensitise students more to music and to enhance their musical competencies, music lessons 
should lead to learning about artistic achievements through the analysis of musical components, musical-stylistic periods, but also to assessment and evaluation of music. An important step forward is the experience of the whole music piece in the musical and non-musical space, i. e. the acquisition of a complete picture of music in human history, the life of composers, works in the socio-political context and in correlation with fine arts, geography, history, literature, philosophy, architecture, etc. This is why the focus of listening should be shifted from the cognitive to the cognitive-emotional aspect. Listening to music in a classroom with peers, with teacher's guidance through multimodal activities, and with the possibility of discussing experiences, stimulated imaginations and interpretations, makes a suitable context for enriching the musical experience, expanding knowledge and deepening interest in music (Vidulin, Plavšić, 2020a; 2020b; Vidulin, Plavšić, Žauhar, 2019; 2020).

\section{Gender}

To examine whether there are differences in music preferences regarding students' gender, the Mann-Whitney $U$ test was performed and results are shown in Table 2.

Table 2. Music preference regarding students' gender

\begin{tabular}{|c|c|c|c|c|}
\hline Music piece & $\begin{array}{c}\text { Female students } \\
\qquad \mathbf{n}=\mathbf{2 9 3} \\
\text { Average rank }\end{array}$ & $\begin{array}{l}\text { Male students } \\
\quad n=223 \\
\text { Average rank }\end{array}$ & $\begin{array}{c}\text { Mann- } \\
\text { Whitney } \\
U\end{array}$ & $\mathbf{p}$ \\
\hline $\begin{array}{l}\text { P. Ilych Tchakovsky: Piano Concerto No. } \\
1 \text { in B-flat minor for piano and orchestra }\end{array}$ & 273.97 & 238.17 & 37202 & 0.004 \\
\hline $\begin{array}{l}\text { L. van Beethoven: Sonata Pathétique op. } \\
\qquad 13 \text { no. } 8, \text { I. }\end{array}$ & 272.66 & 239.89 & 36819.5 & 0.011 \\
\hline $\begin{array}{l}\text { K. Penderecki: Threnody to the Victims } \\
\text { of Hiroshima }\end{array}$ & 243.54 & 278.15 & 28286.5 & 0.005 \\
\hline $\begin{array}{l}\text { J. S. Bach: Brandenburg concerto no. 2, } \\
\text { I. Allegro }\end{array}$ & 276.10 & 235.38 & 37825.5 & 0.001 \\
\hline $\begin{array}{c}\text { W. A. Mozart: A Little Night Music } \\
\text { (Serenade no. } 13 \text { for strings in G major, } \\
\text { K 525) }\end{array}$ & 276.87 & 234.37 & 38050.5 & 0.001 \\
\hline $\begin{array}{l}\text { C. Debussy: Prelude to the Afternoon of } \\
\text { a Faun, L } 86\end{array}$ & 269.53 & 244.01 & 35900 & 0.048 \\
\hline F. Chopin: Nocturne, op. 9, no. 2 & 294.81 & 210.79 & 43308 & 0.001 \\
\hline $\begin{array}{l}\text { A. Vivaldi: Spring, op. } 8 \text { RV 269, I. } \\
\text { Allegro }\end{array}$ & 276.65 & 234.65 & 37987 & 0.001 \\
\hline G. Gershwin: Rhapsody in Blue & 260.82 & 255.45 & 33349.5 & 0.676 \\
\hline
\end{tabular}




\begin{tabular}{ccccc}
\hline $\begin{array}{c}\text { F. Mendelssohn: A Midsummer Night's } \\
\text { Dream, Wedding March, op. 61 }\end{array}$ & 272.30 & 240.37 & 36712 & 0.008 \\
\hline $\begin{array}{c}\text { L. Boccherini: Menuet, op. 11, no. 5 (G } \\
\text { 275) }\end{array}$ & 279.66 & 230.69 & 38870.5 & 0.001 \\
\hline J.-P. Rameau: The Hen & 251.65 & 267.5 & 30662 & 0.220 \\
\hline G. Fauré: Pavane, op. 50 & 288.13 & 219.56 & 41352.5 & 0.001 \\
\hline P. Boulez: Structures I & 257.35 & 260.01 & 32333.5 & 0.833 \\
\hline M. Ravel: Bolero & 270.52 & 242.71 & 36190.5 & 0.029 \\
\hline
\end{tabular}

As Table 2 shows, in 12 of 15 music pieces, gender differences were found regarding music preference $(p<0.05)$. Out of these 12 music pieces, female students had higher preference in all except one music piece. This finding confirms the second hypothesis. In previous research evidence was found for gender differences in music preferences, in the same direction (Dobrota, Reić Ercegovac, Habe, 2019; Radočaj-Jerković, Škojo, Milinović, 2018). Girls’ preference towards music pieces that can be described as more gentle is typically related to the female gender role (Colley, 2008). In this research the only music excerpt more preferred by boys was K. Penderecki's Threnody to the Victims of Hiroshima. This piece contains abrupt dynamic changes and clusters that depict people's cries and screams while suffering from the A-bomb explosion. Preference for such intense music fits the stereotypical expectations from the men's gender role.

Resulting from the upbringing, gender roles can be shaped differently, according to the cultural norms. Being a place of organised learning, school is an influential hub of students' personal development. By connecting music with the wider societal and historical context, music education in schools can encourage critical approach to any societal norms, especially those that group people to stereotypes.

\section{Attendance of extracurricular music activities}

To explore potential differences in music preferences regarding students' attendance of extracurricular music activities, again the Mann-Whitney $U$ test was performed and results are presented in Table 3. 
Table 3. Music preference regarding students' attendance of extracurricular music activities

\begin{tabular}{|c|c|c|c|c|}
\hline Music piece & $\begin{array}{c}\text { Attend } \\
\mathrm{n}=174 \\
\text { Average rank }\end{array}$ & $\begin{array}{c}\text { Do not attend } \\
\mathrm{n}=342 \\
\text { Average rank }\end{array}$ & $\begin{array}{c}\text { Mann- } \\
\text { Whitney } \\
U\end{array}$ & $\mathbf{p}$ \\
\hline $\begin{array}{l}\text { P. Ilych Tchakovsky: Piano Concerto No. } \\
1 \text { in B-flat minor for piano and orchestra }\end{array}$ & 291.72 & 241.60 & 35543 & 0.001 \\
\hline $\begin{array}{l}\text { L. van Beethoven: Sonata Pathétique op. } \\
13 \text { no. } 8, \text { I. }\end{array}$ & 279.06 & 248.04 & 33332 & 0.021 \\
\hline $\begin{array}{l}\text { K. Penderecki: Threnody to the Victims } \\
\text { of Hiroshima }\end{array}$ & 258.71 & 258.39 & 29791 & 0.980 \\
\hline $\begin{array}{c}\text { J. S. Bach: Brandenburg concerto no. 2, } \\
\text { I. Allegro }\end{array}$ & 263.86 & 255.77 & 30686.5 & 0.543 \\
\hline $\begin{array}{c}\text { W. A. Mozart: A Little Night Music } \\
\text { (Serenade no. } 13 \text { for strings in G major, } \\
\text { K 525) }\end{array}$ & 267.14 & 254.11 & 31256.5 & 0.265 \\
\hline $\begin{array}{l}\text { C. Debussy: Prelude to the Afternoon of } \\
\text { a Faun, } L 86\end{array}$ & 287.97 & 243.51 & 34881.5 & 0.001 \\
\hline F. Chopin: Nocturne, op. 9, no. 2 & 284.57 & 245.24 & 34290 & 0.003 \\
\hline $\begin{array}{l}\text { A. Vivaldi: Spring, op. } 8 \text { RV 269, I. } \\
\text { Allegro }\end{array}$ & 261.28 & 257.08 & 30238 & 0.736 \\
\hline G. Gershwin: Rhapsody in Blue & 287.72 & 243.63 & 34838 & 0.001 \\
\hline $\begin{array}{l}\text { F. Mendelssohn: A Midsummer Night's } \\
\text { Dream, Wedding March, op. } 61\end{array}$ & 261.22 & 257.12 & 30226.5 & 0.744 \\
\hline $\begin{array}{l}\text { L. Boccherini: Menuet, op. } 11, \text { no. } 5 \text { ( } G \\
\text { 275) }\end{array}$ & 270.98 & 252.15 & 31925.5 & 0.162 \\
\hline J.-P. Rameau: The Hen & 250.64 & 262.50 & 28385.5 & 0.381 \\
\hline G. Fauré: Pavane, op. 50 & 287.12 & 243.94 & 34734 & 0.001 \\
\hline P. Boulez: Structures I & 256.62 & 259.46 & 29426.5 & 0.829 \\
\hline M. Ravel: Bolero & 273.22 & 251.01 & 32315 & 0.095 \\
\hline
\end{tabular}

It can be seen in Table 3 that students that attend extracurricular music activities have higher preferences for 6 of 15 music pieces compared to students that do not attend them $(p<0.05)$. No differences among them are found in other 9 music pieces. This result partly supports the third hypothesis. Substantial evidence can be found that people with higher music education prefer more complex music, including classical (e. g. Dobrota, Reić Ercegovac, 2014; Getz, Marks, Roy, 2014; Peery, Peery, 1986). It could be that students that attend extracurricular music activities were more exposed to these six music pieces compared to their peers that have not attended extracurricular music activities. Additionally, they may have learned more about those pieces and composers so they understood them 
better and perceived them more cognitively (Getz, Marks, Roy, 2014). Also, in the extracurricular music activities they may have socialised with peers that share similar music preferences. It is assumed that not only more exposure to such (complex) music and training affects music preference, but also some mediating or moderating factors (e. g. musical abilities, socio-economic status, family members' preferences) have a certain influence.

However, in the majority of music excerpts in this research differences in music preference regarding the attendance of extracurricular music activities did not occur. It can be connected with the methodological constraint - the lack of detailed information about the type and the length of extracurricular activities they took part in.

\section{Familiarity of music}

To reveal whether there are differences in music preferences regarding familiarity of the music piece to students, the Mann-Whitney $U$ test was again performed and results can be observed in Table 4 .

Table 4. Music preference regarding familiarity of the music piece

\begin{tabular}{|c|c|c|c|c|}
\hline Music piece & $\begin{array}{c}\text { Familiar } \\
\text { Average rank } \\
\mathbf{n}\end{array}$ & $\begin{array}{c}\text { Unfamiliar } \\
\text { Average rank } \\
\text { n }\end{array}$ & $\begin{array}{c}\text { Mann- } \\
\text { Whitney } \\
U\end{array}$ & p \\
\hline $\begin{array}{l}\text { P. Ilych Tchakovsky: Piano Concerto No. } \\
1 \text { in B-flat minor for piano and orchestra }\end{array}$ & $\begin{array}{c}285.78 \\
341\end{array}$ & $\begin{array}{c}205.34 \\
175\end{array}$ & 20534 & 0.001 \\
\hline $\begin{array}{l}\text { L. van Beethoven: Sonata Pathétique op. } \\
\qquad 13 \text { no. } 8, \text { I. }\end{array}$ & $\begin{array}{c}389.91 \\
59\end{array}$ & $\begin{array}{c}241.54 \\
457\end{array}$ & 5728.5 & 0.001 \\
\hline $\begin{array}{l}\text { K. Penderecki: Threnody to the Victims } \\
\text { of Hiroshima }\end{array}$ & $\begin{array}{c}370.76 \\
83\end{array}$ & $\begin{array}{c}236.98 \\
433\end{array}$ & 8652 & 0.001 \\
\hline $\begin{array}{l}\text { J. S. Bach: Brandenburg concerto no. 2, } \\
\text { I. Allegro }\end{array}$ & $\begin{array}{c}286.57 \\
276\end{array}$ & $\begin{array}{c}226.22 \\
240\end{array}$ & 25372.5 & 0.001 \\
\hline $\begin{array}{c}\text { W. A. Mozart: A Little Night Music } \\
\text { (Serenade no. } 13 \text { for strings in G major, } \\
\text { K 525) }\end{array}$ & $\begin{array}{l}259.08 \\
503\end{array}$ & $\begin{array}{c}236.08 \\
13\end{array}$ & 2978 & 0.514 \\
\hline $\begin{array}{l}\text { C. Debussy: Prelude to the Afternoon of } \\
\text { a Faun, } L 86\end{array}$ & $\begin{array}{c}337.05 \\
98\end{array}$ & $\begin{array}{c}240.08 \\
418\end{array}$ & 12784.5 & 0.001 \\
\hline F. Chopin: Nocturne, op. 9, no. 2 & $\begin{array}{c}288.60 \\
391\end{array}$ & $\begin{array}{c}164.33 \\
125\end{array}$ & 12666.5 & 0.001 \\
\hline $\begin{array}{l}\text { A. Vivaldi: Spring, op. } 8 \text { RV 269, I. } \\
\text { Allegro }\end{array}$ & $\begin{array}{c}262.25 \\
499\end{array}$ & $\begin{array}{c}148.29 \\
17\end{array}$ & 2368 & 0.001 \\
\hline G. Gershwin: Rhapsody in Blue & $\begin{array}{l}306.27 \\
259\end{array}$ & $\begin{array}{l}210.36 \\
257\end{array}$ & 20908.5 & 0.001 \\
\hline $\begin{array}{l}\text { F. Mendelssohn: A Midsummer Night's } \\
\text { Dream, Wedding March, op. } 61\end{array}$ & $\begin{array}{c}262.57 \\
491\end{array}$ & $\begin{array}{c}178.52 \\
25\end{array}$ & 4138 & 0.002 \\
\hline
\end{tabular}




\begin{tabular}{|c|c|c|c|c|}
\hline $\begin{array}{l}\text { L. Boccherini: Menuet, op. } 11 \text {, no. } 5 \text { (G } \\
\text { 275) }\end{array}$ & $\begin{array}{c}321.12 \\
223\end{array}$ & $\begin{array}{c}210.84 \\
293\end{array}$ & 18705 & 0.001 \\
\hline J.-P. Rameau: The Hen & $\begin{array}{c}323.68 \\
113\end{array}$ & $\begin{array}{c}240.22 \\
403\end{array}$ & 15404 & 0.001 \\
\hline G. Fauré: Pavane, op. 50 & $\begin{array}{c}322.90 \\
155\end{array}$ & $\begin{array}{c}230.85 \\
361\end{array}$ & 17995 & 0.001 \\
\hline P. Boulez: Structures I & $\begin{array}{c}342.40 \\
92\end{array}$ & $\begin{array}{c}240.29 \\
424\end{array}$ & 11785 & 0.001 \\
\hline M. Ravel: Bolero & $\begin{array}{c}296.71 \\
290\end{array}$ & $\begin{array}{c}209.46 \\
226\end{array}$ & 21688 & 0.001 \\
\hline
\end{tabular}

As Table 4 presents, students prefer $(\mathrm{p}<0.01)$ familiar music pieces more than unfamiliar, except in one case, in which almost everyone found the music piece familiar. This finding strongly confirms the fourth hypothesis. Preference for the familiar sounds can be traced in the new-borns (Ullal-Gupta et al., 2013) and it is repeatedly confirmed over the life span (e.g. Ward, Goodman, Irwin, 2014; Williams 2016; 2018). Such a finding can have educational implications, as this variable can be easily manipulated in music education. If repeated exposure to the same music piece can contribute to music liking, iterative listening can be incorporated in the didactical articulation of the music education. If art music is distant from children and adolescent's music preference, the distance can be reduced by providing them with more listening experience. There is evidence that is can have positive influence in liking the music piece more (Vidulin, Plavšić, Žauhar, 2020).

Taken together, findings in this research provide substantial evidence to LeBlanc's model of music preferences (1982). Namely, the explored variables, age, gender, memory and music education, are listed in the model on the fourth level as having influence on music preferences. From the music teachers' perspective, this provides a theoretical base for developing didactical approaches that take into consideration students' age and awareness of societal gender roles. Then they can choose activities related to music listening to engage students according to their age interests, encourage them to tackle the societal norms, and ensure that the music pieces are repeated to become more familiar. 


\section{CONCLUSION}

As mentioned in the Kurikulum (2019), students' active involvement in music and participation in the cultural life of the community are the expected learning outcomes. Through music they should broaden their horizons, not only in notions about art and culture, but also about the variety of values of the regional, national and world heritage. This can develop them as citizens of the world. Since students' music preference plays an important role in their liking of the music education in school, it is useful for teachers to know how to adapt their teaching strategies to make them more efficient. The results of this research confirm that preference towards classical music declines with age in late childhood and adolescence, that female students prefer classical music and that students prefer music that is familiar to them. Extracurricular music activities do not unequivocally contribute to music preference.

Since music listening is the central activity in music education subjects in Croatian schools (Nastavni plan i program [Teaching plan and programme], 2006), and it is mostly approached in the analytical cognitive way, there is room for enriching the existing teaching approach. It can be done by implementing a range of activities that encourage student's understanding of broader societal, historical and psychological aspects related to a music piece, as well as by enhancing the emotional and holistic experience of music (Vidulin, Plavšić, 2020a; 2020b; Vidulin, Plavšić, Žauhar, 2020).

As already mentioned, the limitation of the research lies in the lack of information about the type and length of extracurricular music activities.

To conclude, a music piece, regardless of its genre, needs to be experienced, thought about, understood, put in wider, both musical and non-musical, contexts, and it will thus enrich students' life. That is why music should remain an integral part of their education. 


\section{REFERENCES}

1. Bonneville-Roussy, A., Rentfrow, P. R., Xu, M. K., Potter, J. (2013). Music through the ages: Trends in musical engagement and preferences from adolescence through middle adulthood. Journal of Personality and Social Psychology, 105 (4): 703-717.

2. Brđanović, D. (2014). Glazbene preferencije učenika srednje glazbene škole. Napredak, 154 (1-2): 47-64.

3. Clark, S. S., Giacomantonio, S. G. (2015). Toward predicting prosocial behavior: Music preference and empathy differences between adolescents and adults. Empirical Musicology Review, 10 (1): 50-65.

4. Colley, A. (2008). Young people's musical taste: relationship with gender and gender-related traits. Journal of Applied Social Psychology, 38 (8): 2039-2055.

5. Delsing M. J. M. H., Ter Bogt T. F. M., Engels R. C. M. E., Meeus W. H. J. (2008). Adolescents' music preferences and personality characteristics. European Journal of Personality, 22: 109-130.

6. Corbeil, M., Trehub, S. E., Peretz, I. (2013). Infants prefer speech to singing only when speech sounds happier. Frontiers in Psychology, 4, Article 372.

7. Costa-Giomi, E., Illari, B. (2014). Infants' preferential attention to sung and spoken stimuli. Journal of Research in Music Education, 62 (2): 188-94.

8. Demorest, S., Schultz, S. J. M. (2004). Children's preference for authentic versus arranged versions of world music recordings. Journal of Research in Music Education, 52 (4): 300-313.

9. Dobrota, S., Ćurković, G. (2016). Glazbene preferencije djece mlađe školske dobi. Život i škola, 52 (15-16): 105-114.

10. Dobrota, S., Mikelić, M. (2012). Glazbene preferencije učenika prema glazbi različitog tempa. Metodički ogledi, 19 (2): 137-146.

11. Dobrota, S., Reić Ercegovac, I. (2014). Students' musical preferences: The role of music education, characteristics of music and personality traits. Croatian Journal of Education, 16 (2): 363-384.

12. Dobrota, S., Reić Ercegovac, I. (2017). Music preferences with regard to music education, informal influences and familiarity of music amongst young people in Croatia. British Journal of Music Education, 34 (1): 41-55.

13. Dobrota, S., Reić Ercegovac, I., Habe, K. (2019). Gender differences in musical taste: The mediating role of functions of music. Društvena istraživanja, 28 (4): 567-586.

14. Droe, K. (2006). Music preference and music education: A review of literature. Update: Applications of Research in Music Education, 24 (2): 23-32.

15. Elvers, P., Omigie, D., Fuhrmann, W., Fischinger, T. (2015). Exploring the musical taste of expert listeners: Musicology students reveal tendency toward omnivorous taste. Frontiers in Psychology, 6: 1252 .

16. Freitas, C., Manzato, E., Burini, A., Taylor, M. J., Lerch, J. P., Anagnostou, E. (2018). Neural correlates of familiarity in music listening: A systematic review and a neuroimaging meta-analysis. Frontiers in neuroscience, 12: 686.

17. Getz, L. M., Marks, S., Roy, M. (2014). The influence of stress, optimism, and music training on music uses and preferences. Psychology of Music, 42 (1): 71-85. 
18. Ginocchio, J. (2009). The effects of different amounts and types of music training on music style preference. Bulletin of the Council for Research in Music Education, 182: 7-18.

19. Habe, K., Dobrota, S., Reić Ercegovac, I. (2018). The structure of musical preferences of youth: cross-cultural perspective. Musicological Annual, 54 (1): 141-156.

20. Hargreaves, D. J., North, A. C., Tarrant, M. (2006). Musical preference and taste in childhood and adolescence. In G. E. McPherson (Ed.), The child as musician: A handbook of musical development (pp. 135-154). New York: Oxford University Press.

21. Hargreaves, D. J., North, A. C., Tarrant, M. (2015). How and why do musical preferences change in childhood and adolescence? The child as musician: A handbook of musical development. Oxford Scholarship Online: 303-322.

22. Hash, P. M. (2009). Undergraduate non-music major preferences for western art music. Contributions to Music Education, Ohio Music Education Association, 36 (1): 9-24.

23. Johnston, R. (2016). The effect of repetition on preference ratings for select unfamiliar musical examples: Does preference transfer? Psychology of Music, 44 (3): 514-526.

24. Kim, J. (2011). Affective states, familiarity and music selection: Power of familiarity. International Journal of Arts and Technology, 4 (1): 74-89.

25. Kurikulum nastavnog predmeta Glazbena kultura za osnovne škole i Glazbena umjetnost za gimnazije (2019). Ministarstvo znanosti i obrazovanja.

26. LeBlanc, A. (1982). An interactive theory of music. Journal of Music Therapy, 19 (1): 28-45.

27. Madsen, C. K., Geringer, J. M. (2015). Responses of multi-aged music students to mid-20thcentury art music: A replication and extension. Journal of Research in Music Education, 63 (3): 336-348.

28. Nastavni plan i program (2006). Zagreb: Ministarstvo znanosti, obrazovanja i sporta.

29. North, A. C., Hargreaves, D. J., O’Neill, S. A. (2000). The importance of music to adolescents. British Journal of Educational Psychology, 70 (2): 255-275.

30. Peery, J. C., Peery, I. W. (1986). Effects of exposure to classical music on the musical preferences of preschool children. Journal of Research in Music Education, 34 (1): 24-33.

31. Radočaj-Jerković, A., Škojo, T., Milinović, M. (2018). Zborsko pjevanje kao oblik neformalnog učenja i njegov utjecaj na formiranje dječjih glazbenih preferencija. Školski vjesnik, 67 (2): 311329.

32. Radoš, A. (2014). Povezanost savjesnosti i glazbenih preferencija. Diplomski rad. Zagreb: Filozofski fakultet.

33. Reić Ercegovac, I., Dobrota, S., Surić, S. (2017). Listening to music and music preferences in early adolescence. Metodički obzori, 12 (24): 6-23.

34. Škojo, T. (2019). Odnos glazbenih preferencija srednjoškolaca, glazbenog obrazovanja i sociodemografskih varijabli. Metodički ogledi, 26 (2): 33-58.

35. Šulentić Begić, J., Begić, A. (2014). Glazbene preferencije učenika I. gimnazije u Osijeku. In M. Brekalo, I. Žužul (Eds.), Međunarodni interdisciplinarni znanstveni skup kultura, društvo, identitet - europski realiteti (pp. 844-861). Osijek: Sveučilište J. J. Strossmayera, Zagreb: Institut društvenih znanosti Ivo Pilar. 
36. Trbojević, F. (2019). Kulturni kapital mladih: preferencije i transmisija popularnih glazbenih žanrova među studentima Sveučilišta u Zagrebu. Medijska istraživanja, 25 (2): 45-67.

37. Ullal-Gupta, S., Vanden Bosch der Nederlanden, C. M., Tichko, P., Lahav, A., Hannon, E. E. (2013). Linking prenatal experience to the emerging musical mind. Frontiers in systems neuroscience, $7: 48$.

38. Vidulin, S. (2013). Propitivanje ostvarenja cilja nastave glazbe u kontekstu vremena glazbene hiperprodukcije. Arti musices, 44 (2): 201-226.

39. Vidulin, S., Plavšić, M. (2020a). Students' reflections and emotions in the context of the cognitiveemotional approach to listening to music. In: V. Svalina (Ed.), Glazbena pedagogija u svjetlu sadašnjih i budućih promjena 6 (93-106). Osijek: Sveučilište J. J. Strossmayera.

40. Vidulin, S., Plavšić, M. (2020b). Contribution of cognitive-emotional approach to music listening on students' cognitive and emotional experience. Musicological Annual, 56 (1): 225-241.

41. Vidulin, S., Milovan Delić, I., Valić J. (2020). Influence of music on students' psychophysiological well-being. The Journal of the Interdisciplinary Society for Quantitative Research in Music and Medicine, 5: 74-100.

42. Vidulin, S., Plavšić, M., Žauhar, V. (2019). Usporedba spoznajnog i emocionalnog aspekta slušanja glazbe u glazbeno-pedagoškom kontekstu osnovne škole. Metodički ogledi, 26 (2): 9-32.

43. Vidulin, S., Plavšić, M., Žauhar, V. (2020). Spoznajno-emocionalno slušanje glazbe u školi. Pula: Sveučilište Jurja Dobrile u Puli, Rijeka: Filozofski fakultet u Rijeci.

44. Vidulin-Orbanić, S. (2012). Utjecaj glazbene nastave na (glazbenu) kulturu učenika. In N. Hrvatić, A. Klapan (Eds.) Pedagogija i kultura 1 (pp. 419-430). Zagreb: Hrvatsko pedagogijsko društvo.

45. Ward, M. K., Goodman, J. K., Irwin, J. R. (2014). The same old song: The power of familiarity in music choice. Marketing Letters, 25 (1): 1-11.

46. Williams, M. L. (2016). The influence of genre and musical training on continuous versus summative ratings of listener enjoyment and response times. Doktorska disertacija, Florida State University, College of Music.

47. Williams, M. L. (2018). The influence of genre and musical training on ratings of listener enjoyment. Bulletin of the Council for Research in Music Education, 217: 67-83. 


\section{PREFERENCIJE STUDENATA GLAZBE PREMA KLASIČNOJ GLAZBI}

\section{SAŽETAK}

Glazbene preferencije mogu biti povezane s brojnim grupama faktora, kao što sugerira LeBlancova Interaktivna teorija glazbenih preferencija. U ovome se radu istraživao odnos preferencija učenica i učenika prema klasičnoj glazbi i četiri faktora iz LeBlancova modela: dobi i roda učenika i učenica, njihova pohađanja izvanškolske glazbene poduke i poznatosti skladbi. Petnaest glazbenih ulomaka iz razlicitih glazbeno-povijesnih razdoblja predstavljeno je uzorku od 516 učenika $i$ učenica od 7 do 18 godina. Rezultati otkrivaju umjerenu negativnu korelaciju izmedu dobi $i$ preferencije prema klasičnoj glazbi. Veća je preferencija pronađena kod učenica te za poznate skladbe. Nisu se pokazale razlike u glazbenoj preferenciji između učenica i učenika koji pohađaju i onih koji ne pohađaju izvanškolsku glazbenu poduku. Nalazi istraživanja u velikoj mjeri potvrđuju LeBlancov model. Dane su preporuke za poučavanje.

Ključne riječi: dob, rod, glazbene preferencije, poznatost, LeBlancov model. 